Rev. Elev. Méd. véf. Pays trop. 1967 20, 2 (349-350).

\title{
Note sur deux cas originaux de charbon Bactéridien en Haute-Volta
}

\author{
por M. LEFÈVRE ef R. GIDEL
}

\begin{abstract}
RÉSUMÉ
Deux cas de charbon bactéridien ont été observés en Haute-Volta sur des antilopes élevées en coptivité. Les auteurs qui n'ont pu préciser le mode de contamination émettent l'hypathèse d'une origine alimentaire probable de cette contamination.
\end{abstract}

Ces cas concernent deux antilopes élevées en captivité, la mère et la fille, âgées respectivement de huit et un an et appartenant à l'espèce Trogelaphus Scriptus ou antilope harnachée, appelée encore Guib harnaché ou Bushbuck des chasseurs (famille des bovidés, sous-famille des tragelaphinés, genre Tragelaphus).

Depuis leur naissance, elles étaient gardées en enclos par leur propriétaire à Bobo-Dioulasso. Jusqu'au 15 juillet 1965, date à laquelle survint le premier décès, les deux animaux étaient en parfaite santé. Le 15 juillet au matin, la plus jeune fut trouvée morte : 24 heures plus tard, la seconde était emportée de la même façon foudroyante.

Le diagnostic de charbon bactéridien fut évoqué dès l'autopsie du premier animal qui présentait une rate hypertrophiée avec pulpe boueuse ef noirâtre, une hépatomégalie congestive ef des hémorragies multiples du tissu congestif.

Des prélèvements furent faits au niveau de la rate, du foie et de la moelle d'un os long. Des colorations de Gram effectuées sur les empreintes de ces trais organes montrèrent de nombreux

\footnotetext{
* Nous remercions vivement M. MILOGO TOLO Simon, infirmier-vétérınaire principal du Service de l'Elevage à Bobo-Dioulasso qui, appelé en premier lieu par le propriétaire, eut le mérite d'évoquer de lui-même le diagnostic de charbon bactéridien ef d'attirer notre aftention sur ce foyer.
}

bacilles Gram positifs, à bouts carrés, isolés ou présentant l'agencement caractéristique en tiges de bambous. Ces constatations furent sanctionnées par la mise en culture immédiate et l'inoculation au cobaye.

La deuxième antılope présenta les mêmes lésions à l'autopsie, à ceci près que la rate, tout en étant boueuse et noirâtre à la coupe, n'était que très modérément hypertrophiée. II fut procédé aux mêmes prélèvements que précédemment ; en outre, le cœur, après ligature ef section des gros vaisseaux fut transporté au laboratoire où le sang fut ponctionné stérilement et examiné sous le microscope avant ensemencement et inoculation.

Les mêmes constatations furent faites sur les frottis colorés. De plus, l'examen du sang entre lame et lamelle, en contraste de phase, montra des bacilles de morphologie identique, immobiles et entourés d'une épaisse capsule hyaline très réfrıngente, rendue plus nette encore par l'adjonction d'encre de chine à la préparation. Cultures ef inoculations furent également réalisées à partir des différents prélèvements.

Le diagnostıc bactériologique fit l'objet de deux études parallèles, l'une conduisant de l'isolement du germe par culture à partir des divers prélèvements à la mise en évidence de son pouvoir pathogène chez le cobaye, l'autre partant des propriétés sélectives de ce pouvoir pathogène chez le cobaye pour aboutir à l'iso- 
lement en culture pure des souches en cause. Celles-ci firent l'objet d'une étude bactériologique complète qui confirma qu'il s'agissait bien de deux souches typiques de Bacteridium Antracis.

Deux modes de contamination semblent pouvoir être retenus. Le premier fait appel à une contamination tellurique directe par un sol souillé de longue date. Le second mode de contamination envisagé est d'origine alimentaire. Cette dernière hypothèse nous semble plus probable que la première, car l'une des antilopes vivait depuls huit ans dans le même enclos et elles étalent toutes deux nourries en partie de fourrage de nature grossière récolté dans les environs de la ville et acheté au marché de BoboDioulasso par le propriétaire. Or, le charbon bactéridien existe à l'état endémique dans la région et des foyers ont été observés aux abords mêmes de la ville. Toutefois, des recherches de spores à partir d'échantillons de terre et de débris de fourrage recueiliis une semaıne plus tard dans l'enclos et inoculés à des cobayes après broyage et chauffage d̀ $65^{\circ} \mathrm{C}$ n'ont pas permis de confirmer cette hypothèse.

Elle demeure néanmoins à nos yeux la plus vraisemblable.

O. C. C. G. E. Centre MURAZ
Bobo-Dioulasso (Haute-Volta).

\section{SUMMARY}

Note on two original cases of Anthrax in Upper Volta

Two cases of Anthrax have been recorded in Upper Volta in antelopes reared in captivity. The way of infection could not be ascertained. It is suggested that the contamination could be of food-borne origine.

\section{RESUMEN}

Nota sobre dos casos originales de carbunco bacteridiano en Alta-Volta

En Alta-Volta se observaron dos casos de carbunco bacteridiano en antilopes criadas en cautividad. No fué posible determinar el modo de contaminación. Los autores sugieren que dicha contaminación podrıa tener su origen en la alimentación. 